\title{
Genetic diversity of thermoduric spoilage microorganisms of milk from Brazilian dairy farms
}

\author{
J. C. Ribeiro Júnior, ${ }^{* 1}$ R. Tamanini, ${ }^{*}$ A. L. M. de Oliveira,† A. A. Alfieri, ${ }^{*}$ and V. Beloti ${ }^{*}$ \\ ${ }^{*}$ National Institute of Science and Technology for the Dairy Production Chain (INCT-Leite), and \\ †Biochemistry and Biotechnology Department, State University of Londrina, PO Box 10.011, Paraná, Brazil, 86.057-970
}

\begin{abstract}
When correctly pasteurized, packaged, and stored, milk with low total bacterial counts (TBC) has a longer shelf life. Therefore, microorganisms that resist heat treatments are especially important in the deterioration of pasteurized milk and in its shelf life. The aim of this work was to quantify the thermoduric microorganisms after the pasteurization of refrigerated raw milk samples with low TBC and to identify the diversity of these isolates with proteolytic or lipolytic potential by RFLP analysis. Twenty samples of raw milk were collected in bulk milk tanks shortly after milking in different Brazilian dairy farms and pasteurized. The mean thermoduric count was $3.2( \pm 4.7) \times 10^{2} \mathrm{cfu} / \mathrm{mL}$ (2.1\% of the TBC). Of the 310 colonies obtained, $44.2 \%$ showed milk spoilage potential, $32.6 \%$ were proteolytic and lipolytic simultaneously, $31 \%$ were exclusively proteolytic, and 48 (36.4\%) were only lipolytic. Regarding the diversity, 8 genera were observed (Bacillus, Brachybacterium, Enterococcus, Streptococcus, Micrococcus, Kocuria, Paenibacillus, and Macrococcus); there was a predominance of endospore-forming bacteria (50\%), and Bacillus licheniformis was the most common (34.1\%) species. Considering the RFLP types, it was observed that the possible clonal populations make up the microbiota of different milk samples, but the same milk samples contain microorganisms of a single species with different RFLP types. Thus, even in milk with a high microbiological quality, it is necessary to control the potential milk-deteriorating thermoduric microorganisms to avoid the risk of compromising the shelf life and technological potential of pasteurized milk.
\end{abstract}

Key words: lipolytic, milk spoiler, proteolytic, thermotolerant

Received October 5, 2017

Accepted January 26, 2018.

${ }^{1}$ Corresponding author: ribeirojuniorjc@gmail.com

\section{INTRODUCTION}

Pasteurization is an efficient process for eliminating all pathogenic microorganisms, thus providing microbiologically safe milk for consumption and reducing the amount of deteriorating microorganisms (Sørhaug and Stepaniak, 1997; Lewis, 2003; Knight et al., 2004). However, the thermal processing of raw milk is not sufficient to eliminate all the microorganisms capable of causing deterioration. Thermoduric microorganisms resist the pasteurization process of milk and use components, such as proteins and fat, as nutrient sources, causing organoleptic changes and a reduced product shelf life (Hull et al., 1992; Huck et al., 2007).

Thermoduric microorganisms can influence the shelf life of pasteurized milk (Durak et al., 2006; Huck et al., 2007), together with the enzymatic activity of the proteases and lipases produced by spoilage microorganisms - mainly psychrotrophs - in raw milk (Fairbairn and Law, 1986; Sørhaug and Stepaniak, 1997; Marchand et al., 2008) and the effect of endogenous proteases, such as plasmin (Bastian and Brown, 1996; Murphy et al., 2016), the type of packaging (Petrus et al., 2010), and the contaminants acquired after pasteurization.

Endospore-forming microorganisms, mainly in the genera Bacillus and Paenibacillus, are often described as being responsible for reducing the shelf life of pasteurized milk (Huck et al., 2007; Ranieri et al., 2009, 2012). However, other nonsporulated microorganisms can resist pasteurization (Buehner et al., 2014; Ribeiro Júnior et al., 2017), such as Streptococcus and Enterococcus species (Delgado et al., 2013).

In Brazil, the poor quality of raw milk on farms and the deficiencies in the processing and packaging of pasteurized milk reduce the shelf life of milk to only a few days. Microorganisms capable of resisting the pasteurization process in vegetative forms are of major importance in the dairy industry in that they give Brazilian pasteurized milk a short shelf life. However, little is known about the identity and proteolytic and lipolytic potential of the thermoduric microbiota in Brazilian milk, and it is difficult to determine the origin of and 
control the milk contamination by these microorganisms in dairy farms.

In contrast to most Brazilian dairy farms, some Brazilian dairy regions are the gold standard in milk quality and productivity. The municipality of Castro, which is in the southern region of Paraná State, is an example of this gold standard. There are properties that produce large daily volumes and have a large number of implemented technical and hygiene practices (Ribeiro Júnior et al., 2015). The animals have a great capacity for milk production, and the microbiological quality of the milk meets international standards $\left(<10^{5} \mathrm{cfu} / \mathrm{mL}\right.$; FDA, 2009), presenting the possibility of producing pasteurized milk with a long shelf life (Ribeiro Júnior et al., 2015).

From the identification of thermoduric microorganisms that are potentially milk proteolytic and lipolytic, it is possible to determine their origin under Brazilian conditions, establish specific strategies for the control of this microbiota in raw milk, and, consequently, increase the shelf life of milk after pasteurization. This process would also preserve the integrity of the raw milk constituents, increase the industrial potential in the production of dairy products, and reduce the technological problems in UHT milk and dairy products (Murphy et al., 2016). Thus, the aim of this study was to quantify the thermoduric microorganisms in milk of high microbiological quality produced in the southern region of Brazil to evaluate the spoilage potential of these microorganisms as well as their diversity and identity as a preliminary step for determining the source of raw milk contamination in Brazilian farms and developing control practices.

\section{MATERIALS AND METHODS}

Twenty samples of raw refrigerated milk were collected and evaluated from the bulk milk tanks of 20 different dairy farms in the region of Castro in Paraná, Brazil. This municipality was recently recognized by the Brazilian federal government as the Brazilian capital of milk. The description of properties has been previously reported by Ribeiro Júnior et al. (2015).

Of these milk samples, $95 \%$ had total bacterial counts $<10^{5} \mathrm{cfu} / \mathrm{mL}$, with a mean of $1.5( \pm 3.4) \times 10^{4} \mathrm{cfu} / \mathrm{mL}$ (Ribeiro Júnior et al., 2018). In closed and continuous flow, the raw milk was precooled before being stored in a bulk tank at $4^{\circ} \mathrm{C}$. The samples were collected in bulk tank immediately after the morning milking. The milk of the afternoon milking of the previous day to the collection was already in the tanks. The samples were collected aseptically, refrigerated, and sent to the
Animal Origin Products Inspection Laboratory at the State University of Londrina, where they were immediately processed.

Thermoduric bacteria were enumerated after heating milk $(5 \mathrm{~mL})$ to a temperature that stimulates pasteurization $\left(62.8 \pm 0.5^{\circ} \mathrm{C}\right.$ for $\left.30 \mathrm{~min}\right)$, followed by immediate refrigeration at $10^{\circ} \mathrm{C}$, in accordance with Frank and Yousef (2004). After treatment, serial dilutions of the samples were performed up to $10^{-3}$ in sterile peptone $(0.001 \%)$ saline $(0.85 \%)$ solution, and duplicates were surface plated $(0.1 \mathrm{~mL})$ on plate count agar (Oxoid, Basingstoke, UK). Plates were incubated at $35 \pm 1^{\circ} \mathrm{C}$ for $48 \mathrm{~h}$.

All isolated colonies obtained on the dilution plates used for counting were spiked on milk agar (Acumedia, Baltimore, MD) supplemented with $10 \%$ reconstituted milk powder solution (10\%) and tributyrin agar (Himedia, Mumbai, India) supplemented at $1 \%$ with tributyrin (Himedia) for their proteolytic and lipolytic potential, respectively (Hantsis-Zacharov and Halpern, 2007). These plates were incubated under the same conditions recommended for thermoduric enumeration (Frank and Yousef, 2004).

The isolates that had deteriorating activity were grown in brain heart infusion broth to extract their genomic DNA by boiling according to Ribeiro Júnior et al. (2016b). Extraction products were subjected to partial amplification of the $16 \mathrm{~S}$ rRNA gene using primers $27 \mathrm{f}$ (5'-GAGTTTGATCMTGGCTCAG-3') and 1492r (5'-GGYTACCTTGTTACGACTT-3'; Osborne et al., 2005). The reactions were carried out with final amounts of $50 \mathrm{ng}$ of template DNA, $100 \mathrm{nmol}$ of each nitrogen base, $1 \times$ buffer, $75 \mathrm{mmol} / \mathrm{L}$ of $\mathrm{MgCl}_{2}$, $20 \mathrm{pmol} / \mathrm{L}$ of each primer, and $2.5 \mathrm{U}$ of Platinum Taq DNA polymerase (Invitrogen, Carlsbad, CA), with a final volume of $50 \mu \mathrm{L}$. The amplification conditions were as follows: 1 cycle of initial denaturation at $94^{\circ} \mathrm{C}$ for $5 \mathrm{~min}$; 35 cycles of $94^{\circ} \mathrm{C}$ for $1 \mathrm{~min}$, annealing at $58^{\circ} \mathrm{C}$ for $1 \mathrm{~min}$, and extension at $72^{\circ} \mathrm{C}$ for $1 \mathrm{~min}$; and 1 final extension step at $72^{\circ} \mathrm{C}$ for $10 \mathrm{~min}$.

To avoid redundancy in the sequencing reactions, the partial 16S rRNA gene amplicons obtained in the reactions described above were subjected to RFLP for hierarchical genetic grouping from the restriction profiles with the enzymes Cfo I (Promega, Madison, WI), TaqI (Ludwig Biotech, Santa Maria, Brazil), RsaI (Invitrogen), and HaeIII (Invitrogen) using the protocols described by the manufacturers.

After the restriction reactions, the products were electrophoresed on a $2 \%$ agarose gel for $60 \mathrm{~min}$ at 70 $\mathrm{V}$. The gels were stained with ethidium bromide $(0.2$ $\mathrm{mg} / \mathrm{L}$ ) and imaged. The images of each restriction pro- 
Table 1. Identification, proportionality, and spoilage potential of thermoduric bacteria isolated from 20 Brazilian milk samples

\begin{tabular}{|c|c|c|c|c|c|}
\hline Identification & $\begin{array}{l}\text { GenBank } \\
\text { accession no. }\end{array}$ & $\begin{array}{l}\text { Total, } \\
\text { no. }(\%)\end{array}$ & $\begin{array}{l}\text { Proteolytic and } \\
\text { lipolytic, no. }(\%)\end{array}$ & $\begin{array}{c}\text { Proteolytic, } \\
\text { no. }(\%)\end{array}$ & $\begin{array}{c}\text { Lipolytic, } \\
\text { no. }(\%)\end{array}$ \\
\hline Bacillus licheniformis & MG561890 & $45(34.1)$ & $16(35.6)$ & $11(24.4)$ & $18(40)$ \\
\hline Streptococcus agalactiae & MG561893 & $11(8.3)$ & $1(9.1)$ & $9(81.8)$ & $1(9.1)$ \\
\hline Bacillus spp. & MG561894 & $6(4.55)$ & $3(50)$ & $2(33.3)$ & $1(16.7)$ \\
\hline Micrococcus aloeverae & MG561895 & $6(4.55)$ & $5(83.3)$ & & $1(16.7)$ \\
\hline Bacillus circulans & MG561898 & $4(3.0)$ & $1(25)$ & $1(25)$ & $2(50)$ \\
\hline Paenibacillus cookii & MG561899 & $4(3.0)$ & & & $4(100)$ \\
\hline Kocuria kristinae & MG561900 & $3(2.3)$ & $1(33.3)$ & $1(33.3)$ & $1(33.3)$ \\
\hline Bacillus clausii & MG561901 & $2(1.5)$ & & & $2(100)$ \\
\hline Bacillus invictae & MG561902 & $2(1.5)$ & & & $2(100)$ \\
\hline Paenibacillus puldeungensis & MG561903 & $2(1.5)$ & & $1(50)$ & $1(50)$ \\
\hline Streptococcus gallolyticus & MG561904 & $2(1.5)$ & & $1(50)$ & $1(50)$ \\
\hline
\end{tabular}

file were analyzed by the software Bionumérics v. 1.50 (Applied Mathematics, Kortrijk, Belgium). The Dice similarity coefficient (Dice, 1945) and the unweighted pair group mean averages algorithm (Sneath and Sokal, 1973) were used. To determine the clusters, a minimum of $50 \%$ phylogenetic similarity was used.

For DNA sequencing, the Sanger method (ABI 3500 Genetic Analyzer, Applied Biosystems, Foster City, CA) was used in both directions. For this, a representative isolate from each cluster was randomly selected for a new PCR reaction of the $16 \mathrm{~S}$ rRNA gene and was subjected to purification (PureLink Genomic DNA Purification Kit, Invitrogen) and quantification (Qubit dsDNA HS Assay Kit, Invitrogen).

The quality of the sequences was evaluated by BioEdit v. 7.2.5 (Hall, 1999), and consensual sequences were generated by CAP 3 (Huang and Madan, 1999). Preliminary identification at the genus level was performed using the Blast tool from the National Center for Biotechnology Information (Bethesda, MD). Sequences were individually aligned by Clustal W with representative strains for all the species of each genus available in the Ribosomal Database Project. The neighbor joining method and the Tamura-Nei model using 1,000 bootstraps in Mega v. 7.0 (Kumar et al., 2016) were used to identify the species by genetic similarity. A representative $16 \mathrm{~S}$ rRNA gene sequence of each identified strain was deposited on GenBank.

\section{RESULTS}

Thermoduric bacteria were quantified and isolated from raw milk samples following the exposure of the milk to pasteurization-like conditions. The thermoduric counts varied between $5 \mathrm{cfu} / \mathrm{mL}$ (milk sample 14) and $1.9 \times 10^{3} \mathrm{cfu} / \mathrm{mL}$ (milk sample 11), with a mean of 3.2 $( \pm 4.7) \times 10^{2} \mathrm{cfu} / \mathrm{mL}$ for the 20 evaluated milk samples. From the plates used for the counts, 310 colonies were selected and confirmed to represent single isolates by passage on nutritive agar medium, of which $132(42.6 \%)$ had milk-deteriorating potential. Of these, $43(32.6 \%)$ were proteolytic and lipolytic simultaneously, 41 (31\%) were exclusively proteolytic, and $48(36.4 \%)$ were only lipolytic (Table 1).

These 132 isolates of potentially thermoduric milkdeteriorating bacteria were grouped by RFLP according to their proteolytic or lipolytic potential in 2 dendrograms. Figure 1 shows the grouping of the proteolytic thermoduric microorganisms, and Figure 2 shows the grouping of the lipolytic microorganisms, representing 41 (I to XLI) and 38 (I to XXXVIII) RFLP types, respectively.

From the representative isolates from the clusters selected for DNA sequencing, identification at the species level by Clustal W and phylogenetic analysis was possible in $94.7 \%$ of the 132 thermoduric isolates; of the remaining 7 isolates, 6 were identified as Bacillus and 1 was identified as Kocuria. The composition of the potential thermoduric microbiota that may contribute to the spoilage of the milk samples is detailed in Table 1.

Regarding the diversity, 8 genera (Bacillus, Brachybacterium, Enterococcus, Streptococcus, Micrococcus, Kocuria, Paenibacillus, and Macrococcus) were found to be milk-deteriorating thermoduric bacteria from the 20 Brazilian milk samples studied by this work. All were 


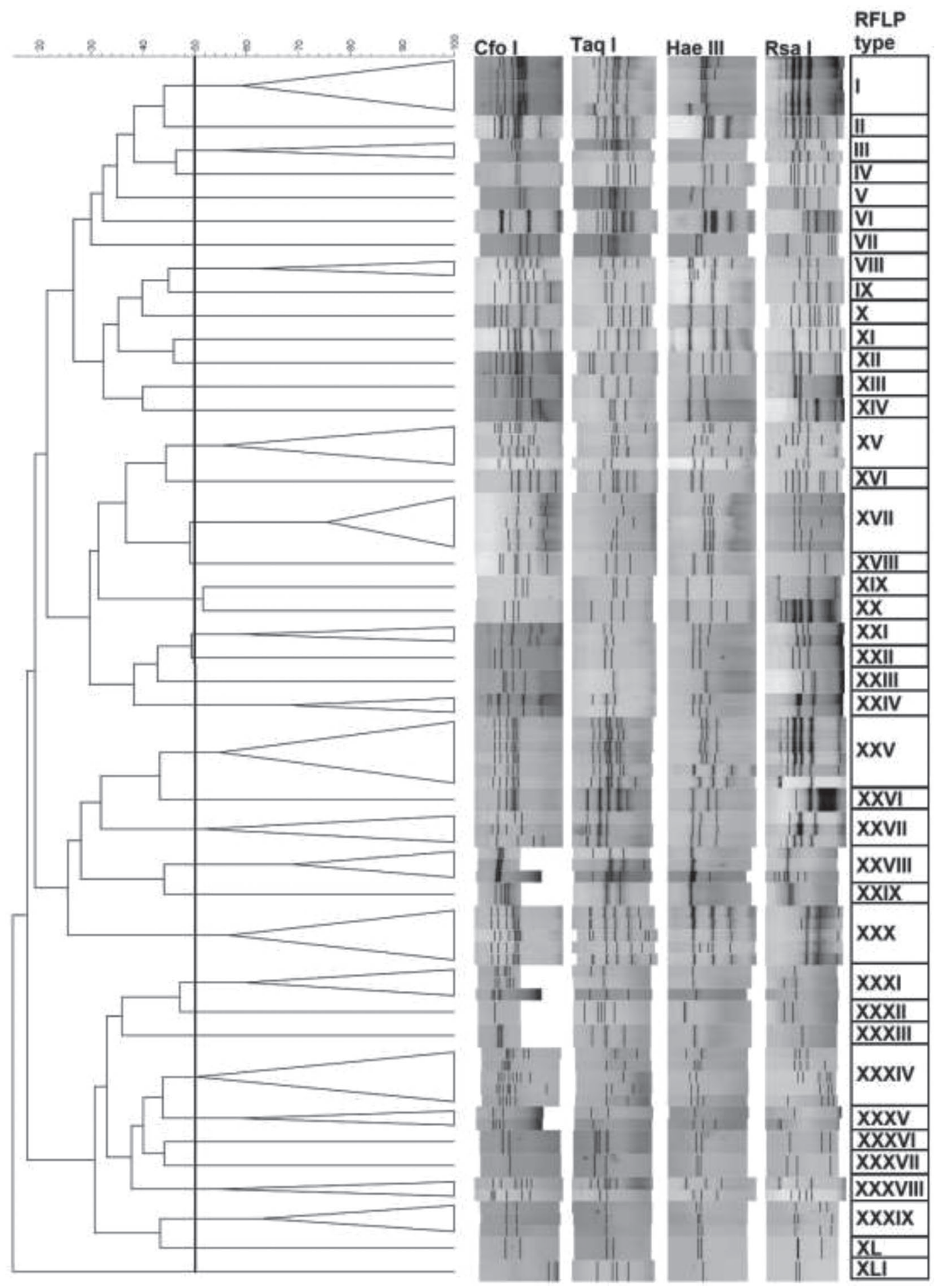

Figure 1. The RFLP data of the proteolytic thermoduric bacteria isolated from 20 Brazilian milk samples, elaborated using enzymatic digestion of the 16S rRNA gene with the enzymes CfoI, TaqI, HaeIII, and RsaI, the Dice coefficient, and the unweighted pair group mean averages algorithm. The vertical line represents the minimum percentage of similarity (50\%) used to determine the 41 RFLP types. 

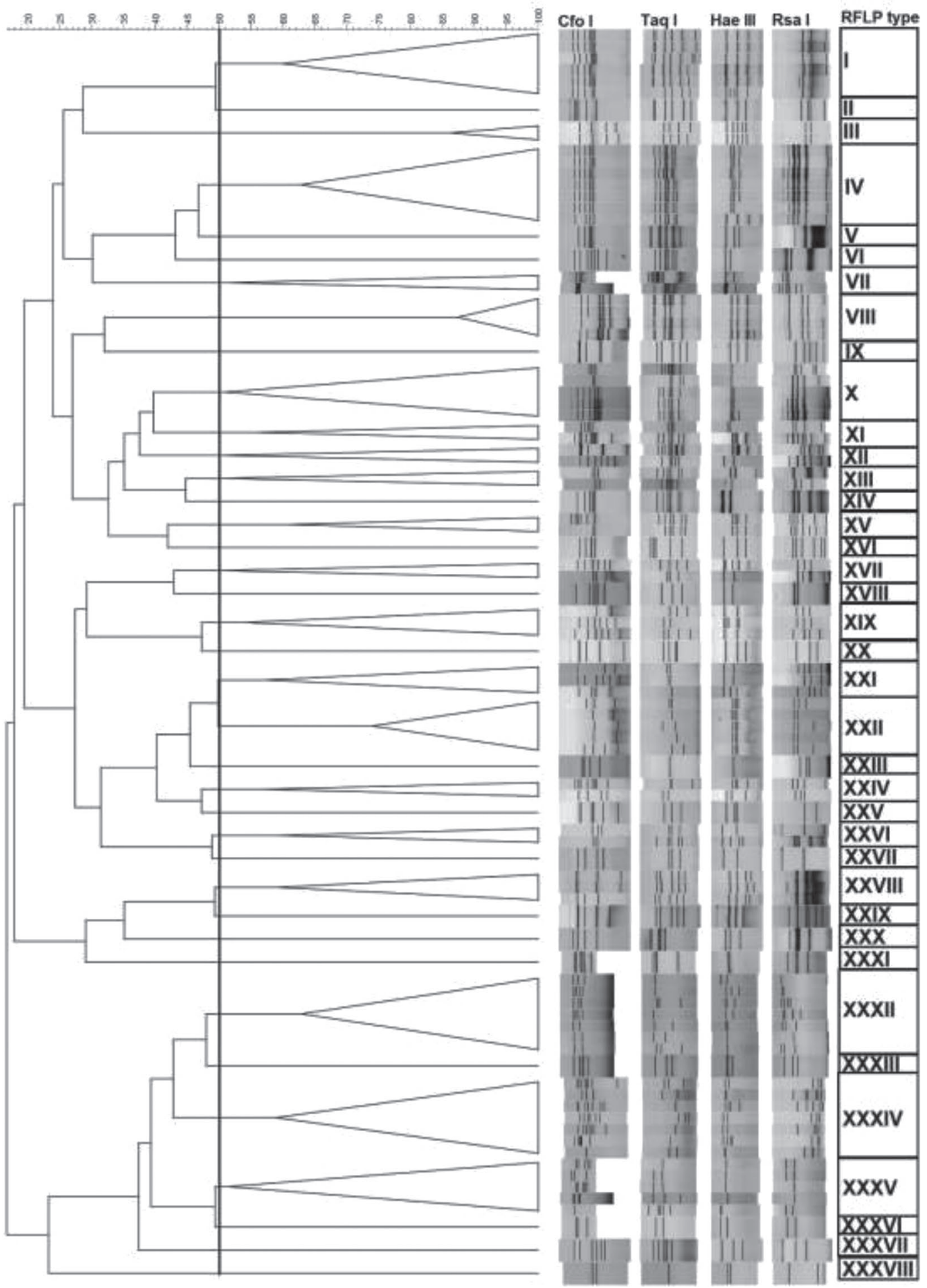

Figure 2. The RFLP data of the lipolytic thermoduric bacteria isolated from 20 Brazilian milk samples, elaborated using enzymatic digestion of the 16S rRNA gene with the enzymes CfoI, TaqI, HaeIII, and RsaI, the Dice coefficient, and the unweighted pair group mean averages algorithm. The vertical line represents the minimum percentage of similarity (50\%) used to determine the 38 RFLP types. 
Table 2. Distribution of RFLP types and identification of potentially milk proteolytic thermoduric bacteria from 20 Brazilian pasteurized milk samples

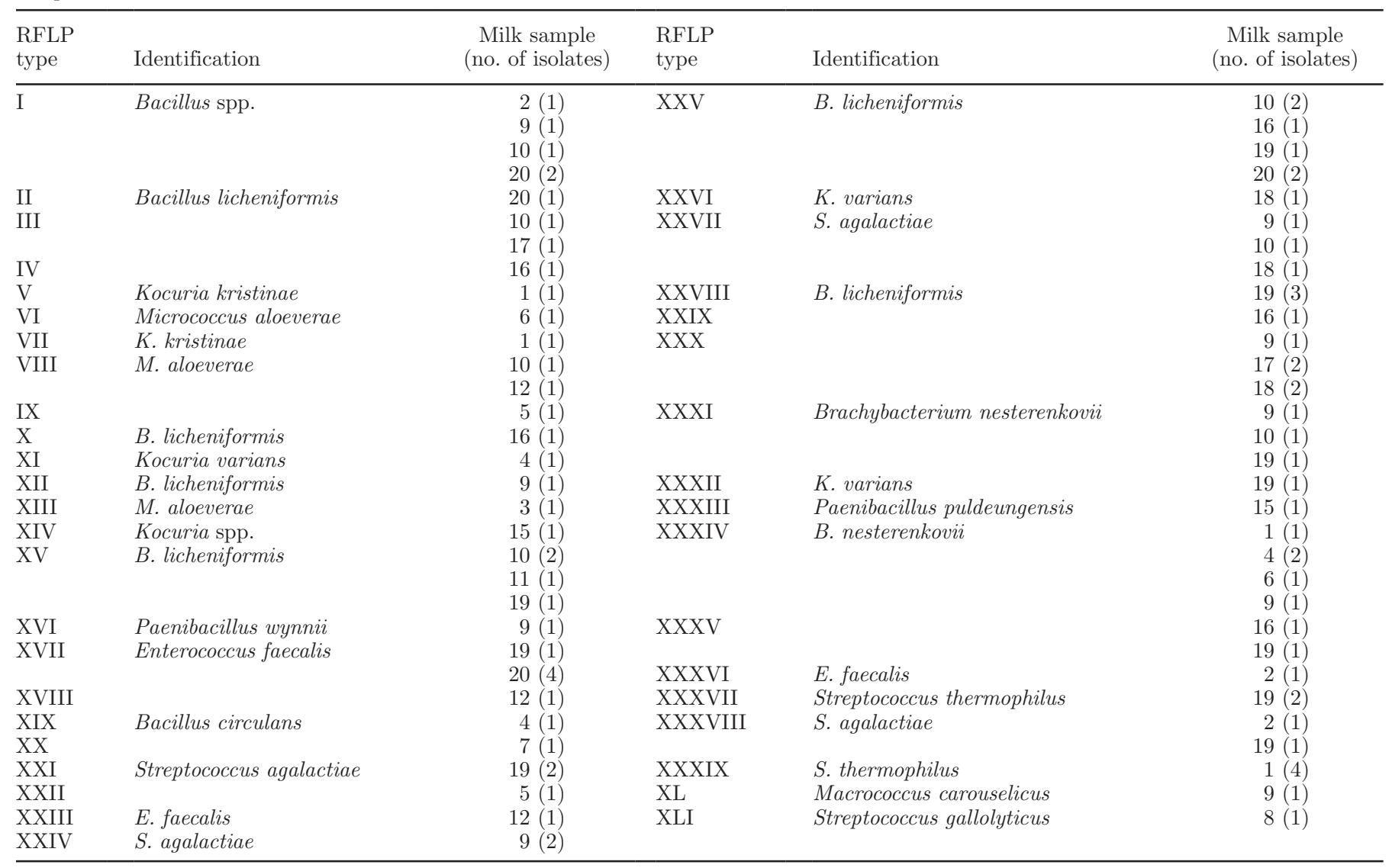

gram-positive microorganisms with known thermoduric potential.

The species Bacillus licheniformis, Brachybacterium nesterenkovii, Enterococcus faecalis, and Streptococcus agalactiae predominated all the potential milk-deteriorating thermoduric bacteria. Bacillus licheniformis, E. faecalis, Br. nesterenkovii, and Micrococcus aloeverae represented $76.7 \%$ of the bacteria that were simultaneously potential proteolytic and lipolytic thermoduric microorganisms. Bacillus licheniformis, S. agalactiae, and Streptococcus thermophilus were among the predominant bacteria that were exclusively proteolytic. Among the exclusively lipolytic bacteria, B. licheniformis, Br. nesterenkovii, and Paenibacillus cookii predominated.

In relation to each RFLP type, the microbial diversity is detailed in Tables 2 and 3 according to the proteolytic and lipolytic potential, respectively. The same bacterial species from the same milk samples had different RFLP types, unlike the same RFLP types that were observed in the microorganisms from different milk samples.

Milk sample 8 had the lowest diversity among the potentially milk-deteriorating thermoduric bacteria, from which only 2 strains of the genus Bacillus (B. licheniformis and $B$. circulans) were isolated. This sample, therefore, contributed only $1.5 \%$ of the total microbiota evaluated by this work (132), as well as sample 14, which presented B. licheniformis and S. agalactiae as potentially milk-deteriorating thermoduric bacteria and thus had greater diversity in relation to sample 8 .

The greatest diversity was observed in milk samples 9 and 19, which presented 7 different species of potentially deteriorating thermoduric bacteria (Tables 2 and 3 ). It is also worth mentioning that the species $B$. licheniformis represented $40 \%$ of the isolates in sample 19 , from which the highest number of potentially deteriorating thermoduric bacteria were recovered $(\mathrm{n}=15)$.

\section{DISCUSSION}

The mean total bacterial count in the present sample was $1.5 \times 10^{4} \mathrm{cfu} / \mathrm{mL}$ (Ribeiro Júnior et al., 2018). Therefore, the average thermoduric count obtained in this study corresponded to only $2.1 \%$ of the total microorganisms present. The thermoduric counts observed in this work $(2.5 \log \mathrm{cfu} / \mathrm{mL})$ were lower than 
in the study by Buehner et al. (2014), which found a mean of $2.76 \log \mathrm{cfu} / \mathrm{mL}$ in 10 samples of refrigerated raw milk in South Dakota in the United States.

Some dairy industries, especially in New Zealand, use a thermoduric count of $1.5 \times 10^{2} \mathrm{cfu} / \mathrm{mL}$ in raw milk as the limit in milk quality payment programs. Only 1 milk sample (number 11) in the present study had a higher score than the New Zealand standard $(2 \times$ $\left.10^{3} \mathrm{cfu} / \mathrm{mL}\right)$, reaffirming the high quality of the milk produced in the studied region.

Regarding the microbial diversity, B. licheniformis was the most frequent species among the spoilage thermoduric microorganisms and was isolated from 16 different milk samples (Tables 2 and 3), with most isolates (40\%) producing lipases, and $35.6 \%$ that simultaneously had proteolytic and lipolytic potential (Table $1)$. Of the 45 isolates of this species, which can be observed in Table 2, 10 RFLP types were classified in the dendrogram of potentially proteolytic thermoduric bacteria (Figure 1) and in 9 of the potentially lipolytic bacteria (Table 3 ).
Among the potential proteolytic bacteria, it is possible to verify that $B$. licheniformis isolates that make up RFLP types III, XV, XXV, and XXX (Figure 2) comprise strains that are isolated from different milk samples, which may indicate that different milk samples may have $B$. licheniformis contamination from the same source.

In addition, milk sample 16 showed the highest diversity among the $B$. licheniformis strains: 4 different RFLP types (IV, X, XXV, and XXIX) were observed in the dendrogram of the proteolytic microorganisms (Table 2). That is, the same milk sample can also be contaminated by different strains of the same species because several papers conclude that microbial spores can contaminate milk via the soil (Vissers et al., 2007), silage (Hull et al., 1992; Buehner et al., 2014), water (Torp et al., 2001), feces (Hull et al., 1992), teats (Christiansson et al., 1999), and milking equipment (te Giffel et al., 2002).

Bacillus licheniformis is often reported as an endospore-forming agent and is the most frequent bacterial

Table 3. Distribution of RFLP types and identification of potentially milk lipolytic thermoduric bacteria from 20 Brazilian pasteurized milk samples

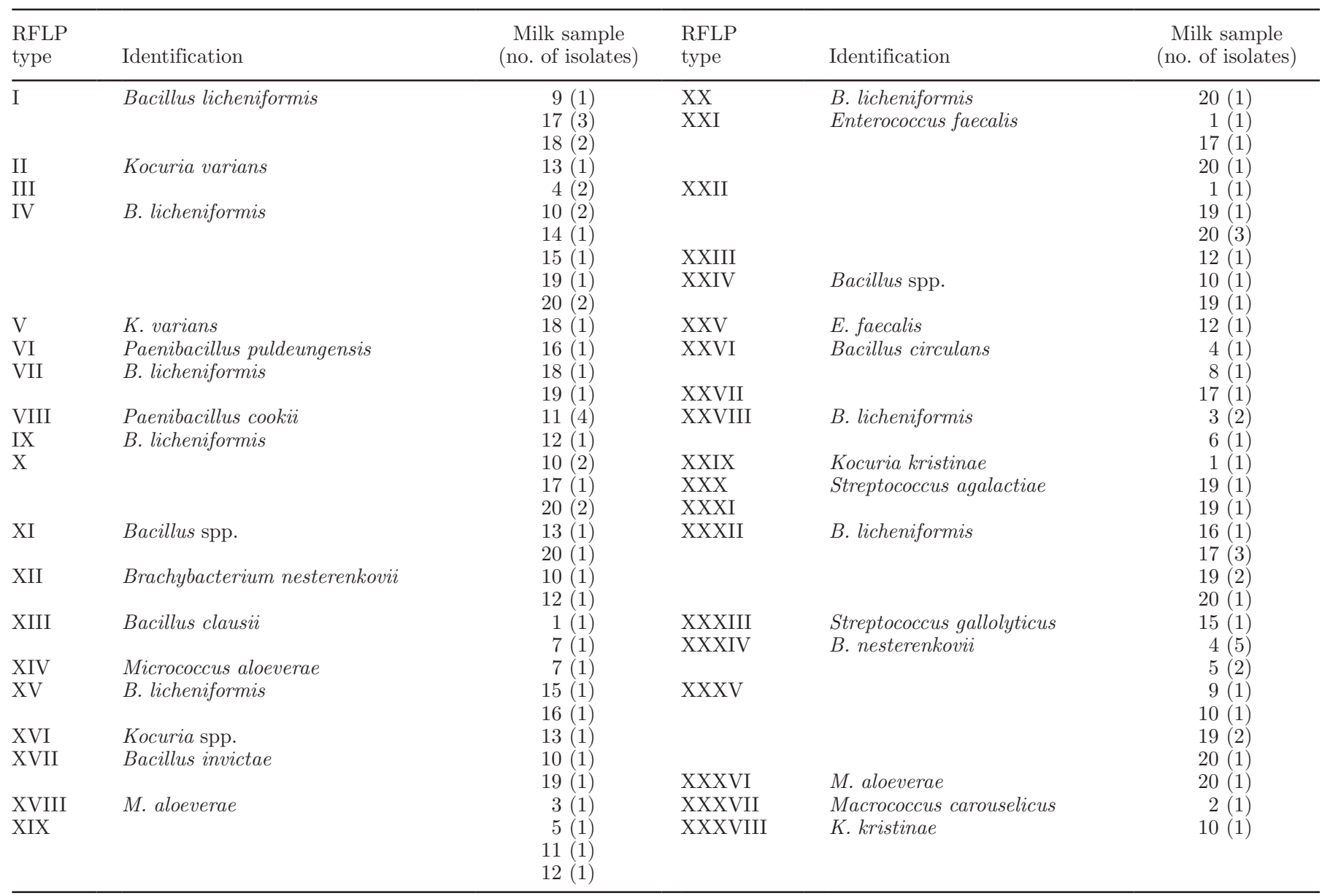


spore producer in milk in several countries (Coorevits et al., 2008; Reginensi et al., 2011; Yuan et al., 2012; Buehner et al., 2014). The bacteria can also multiply at refrigeration temperatures (Doyle et al., 2015; Ribeiro Júnior et al., 2018), allowing them to develop and endure through the milk chain. The fact that the bacteria are sporulated makes their presence even more worrisome because the germination of these spores determines the reduction of shelf life of the pasteurized milk (Huck et al., 2007).

Other microorganisms that are generally described as endospore formers have been described in the thermoduric microbiota in the present work, such as Bacillus circulans and Paenibacillus. The first description of the isolation of microorganisms of the genus Paenibacillus in Brazilian refrigerated raw milk was recently reported by the team from the present study (Ribeiro Júnior et al., 2016a). This genus was isolated from 4 milk samples $(9,11,15$, and 16) that were evaluated in this study (Tables 2 and 3) in 2 different RFLP types for proteolytic (XVI and XXXIII) and lipolytic (VI and VIII) bacteria.

The studies by Huck et al. (2007) and Durak et al. (2006) reported that Bacillus and Paenibacillus represent the greatest potential for reducing the shelf life of pasteurized milk after $14 \mathrm{~d}$, which reaffirms the importance of keeping the contamination of the milk by these microorganisms under control. In the present work, Bacillus and Paenibacillus account for 50\% (66 isolates) of potential spoilage thermoduric microorganisms in the 20 milk samples evaluated. Only 1 milk sample (5) did not present any Bacillus or Paenibacillus isolates, meaning that 19 (95\%) samples did present these genera. As an alternative for the control of these thermoduric microorganisms, the study by Khanal et al. (2014) reports that the ultrasonication of milk can eliminate the vegetative forms of the thermoduric microorganisms of the genus Bacillus.

Brachybacterium nesterenkovii was the second most frequent species that was isolated from the thermoduric spoilage microorganisms in this work (14.4\%), with a predominance of strains with lipolytic activity $(47.4 \%$; Table 1). No previous reports on its thermoduric capacity and milk spoilage potential were found. This species was identified in $10(1,4,5,6,9,10,12,16,19,20)$ of the 20 samples evaluated in the present work. Among the thermoduric bacteria with proteolytic potential (Table 2), 3 RFLP types (XXXI, XXXIV, and XXXV) were observed, and among the potentially lipolytic (Table 3) bacteria, we identified 3 other RFLP types (XII, XXXIV, and XXXV). Thus, although they have a high prevalence in the milk samples, the diversity of $\mathrm{Br}$. nesterenkovii strains is lower in relation to B. licheniformis, being observed in possible clonal populations in different milk samples based on RFLP types.

Enterococcus faecalis also predominated among the potentially deteriorating thermoduric bacteria of this sample unit, being isolated in 7 milk samples $(1,7,12$, $17,18,19$, and 20). Of the total isolates of this species, $42 \%$ were identified only in milk sample 20 (Table 2 ). Possible clonal populations of this species were identified in milk samples 19 and 20 (RFLP type XVII in Figure 1); samples 1, 17, and 20 (XXI RFLP type in Figure 2); and samples 5, 19, and 20 (RFPL type XXII on Figure 2).

A study by McAuley et al. (2012) reported the thermoduric potential of several species of Enterococcus, including the species E. faecalis that was identified by the present work. Another study by the same authors (McAuley et al., 2015) reported that Enterococcus is present in $96 \%$ of raw milk samples in Australia, and E. faecalis is the most common species $(74.3 \%$ of 909 isolates).

A study by Delgado et al. (2013) verified the presence of E. faecium, S. thermophilus, Kocuria spp., Streptococcus spp., and other lactic acid bacteria in pasteurized milk. Some of the autochthonous lactic acid bacteria of raw milk can withstand pasteurization, which is desirable in many technological processes in the production of dairy products (Ortolani et al., 2010) or undesirable if in fluid milk, causing deterioration. Micrococcus and Streptococcus species are often isolated from pasteurized milk (Hull et al., 1992), and cases of mastitis in the herd may be a source of milk contamination by these microorganisms (Taponen et al., 2017).

Flint et al. (1999) also reported the thermoduric potential of $S$. thermophilus and its ability to form biofilms. According to the authors, this species may compromise the quality of pasteurized milk. Six (100\%) strains of this species were identified in the present study; the strains were isolated from 2 different milk samples (1 and 19), had proteolytic activity, and were identified as 2 distinct RFLP types (XXXVII and XXXIX) and possible clonal populations in each milk sample.

In addition, biofilm-forming thermophilic microorganisms, such as $S$. thermophilus, can adhere to the heat exchanger plates of dairy equipment and compromise the quality of the milk processed therein. The study by Knight et al. (2004) proposes cycles to control biofilms to obtain $S$. thermophilus-free pasteurized milk.

Notably, the present work evaluated the mesophilic thermoduric microbiota. Some microorganisms, including spores, may be thermoduric, deteriorating and multiplying in refrigerated temperatures, and are thus 
psychotropic and thermoduric. The study by Ribeiro Júnior et al. (2017) isolated Bacillus pumilus, an endospore-forming bacterium (Buehner et al., 2015) with proteolytic potential, from milk after pasteurization and incubation at $7^{\circ} \mathrm{C}$ for $10 \mathrm{~d}$. The same study also isolated fungal microorganisms in the psychotropic thermoduric spectrum, such as Cladosporium cladosporioides, Geotrichum candidum, and Curvularia geniculatus, all with proteolytic activity, demonstrating the thermal amplitude to which these microorganisms adapt as well as the diversity of this microbiota.

Considering the resistance of thermoduric bacteria to heat treatments and the high percentage of sporulates within them, the best strategy to increase milk quality and its technological potential is to avoid contamination by thermoduric microorganisms during the milking, storage, and transport of raw milk. Therefore, other studies are needed to find the sources of milk contamination by these microorganisms under Brazilian production conditions and to establish strategies to avoid milk contamination.

\section{CONCLUSIONS}

Even in raw milk obtained with low total counts of microorganisms, several thermoduric bacteria have proteolytic or lipolytic potential that can compromise the quality of pasteurized milk. These bacteria are mainly Bacillus and other endospore-forming species as well other nonsporulated bacteria, which can be resistant to milk heat treatments. Therefore, the best way to reduce the presence of these microorganisms in pasteurized milk is to avoid their inclusion in raw milk.

\section{ACKNOWLEDGMENTS}

This study was supported by the following Brazilian institutes: National Council of Scientific and Technological Development (CNPq, Brasília, Brazil; grant no. 305062/2015-8), Brazilian Federal Agency for Support and Evaluation of Graduate Education (CAPES, Brasília, Brazil; process 88887.145705/2017-00), Financing of Studies and Projects (FINEP), and the Araucaria Foundation (FAP/PR, Curitiba, Paraná, Brazil). The authors are grateful for the collaboration of the researchers Elis Lorenzetti (Laboratory of Animal Virology, UEL, State University of Londrina, Londrina, Paraná, Brazil) for support in molecular biology and Renan Augusto Ribeiro and Jakeline Renata Marçon Delamuta (EMBRAPA-Brazilian Agricultural Research Corporation, Soy unity, Londrina, Paraná, Brazil) for training the team in the Bionumerics software.

\section{REFERENCES}

Bastian, E. D., and R. J. Brown. 1996. Plasmin in milk and dairy products: An update. Int. Dairy J. 6:435-457. https://doi.org/10 .1016/0958-6946(95)00021-6.

Buehner, K. P., S. Anand, and G. D. Djira. 2015. Prevalence of thermoduric bacteria and spores in nonfat dry milk powders of Midwest origin. J. Dairy Sci. 98:2861-2866. https://doi.org/10.3168/ jds.2014-8822.

Buehner, K. P., S. Anand, G. D. Djira, and A. Garcia. 2014. Prevalence of thermoduric bacteria and spores on 10 Midwest dairy farms. J. Dairy Sci. 97:6777-6784. https://doi.org/10.3168/jds .2014-8342.

Christiansson, A., J. Bertilsson, and B. Svensson. 1999. Bacillus cereus spores in raw milk: Factors affecting the contamination of milk during the grazing period. J. Dairy Sci. 82:305-314. https://doi .org/10.3168/jds.S0022-0302(99)75237-9.

Coorevits, A., V. Jonghe, J. Vandroemme, R. Reekmans, J. Heyrman, W. Messens, P. Vos, and M. Heyndrickx. 2008. Comparative analysis of the diversity of aerobic spore-forming bacteria in raw milk from organic and conventional dairy farms. Syst. Appl. Microbiol. 31:126-140. https://doi.org/10.1016/j.syapm.2008.03.002.

Delgado, S., C. T. Rachid, E. Fernández, T. Rychlik, A. Alegría, R. S. Peixoto, and B. Mayo. 2013. Diversity of thermophilic bacteria in raw, pasteurized and selectively-cultured milk, as assessed by culturing, PCR-DGGE and pyrosequencing. Food Microbiol. 36:103-111. https://doi.org/10.1016/j.fm.2013.04.015.

Dice, L. R. 1945. Measures of the amount of ecologic association between species. Ecology 26:297-302. https://doi.org/10.2307/ 1932409.

Doyle, C. J., D. Gleeson, K. Jordan, T. P. Beresford, R. P. Ross, G. F. Fitzgerald, and P. D. Cotter. 2015. Anaerobic sporeformers and their significance with respect to milk and dairy products. Int. J. Food Microbiol. 197:77-87.

Durak, M. Z., H. I. Fromm, J. R. Huck, R. N. Zadoks, and K. J. Boor. 2006. Development of molecular typing methods for Bacillus spp. and Paenibacillus spp. isolated from fluid milk products. J. Food Sci. 71:50-56. https://doi.org/10.1111/j.1365-2621.2006.tb08907 .x.

Fairbairn, D. J., and B. A. Law. 1986. Proteinases of psychrotrophic bacteria: Their production, properties, effects and control. J. Dairy Res. 53:139-177. https://doi.org/10.1017/S0022029900024742.

FDA (U.S. Food and Drug Administration). 2009. Standards for grade "A" milk and milk products. Pages 28-31 in Grade "A" Pasteurized Milk Ordinance. US Department of Health and Human Services, Public Health Service, Washington, DC.

Flint, S. H., H. van der Elzen, J. D. Brooks, and P. J. Bremer. 1999. Removal and inactivation of thermo-resistant streptococci colonizing stainless steel. Int. Dairy J. 9:429-436. https://doi.org/10 .1016/S0958-6946(99)00048-5.

Frank, J. F., and A. E. Yousef. 2004. Tests for groups of microorganisms. Pages 281-292 in Standard Methods for the Examination of Dairy Products. 17th ed. H. M. Wehr and J. F. Frank, ed. American Public Health Association, Washington, DC.

Hall, T. A. 1999. BioEdit: A user-friendly biological sequence alignment editor and analysis program for Windows 95/98/NT. Nucl. Acids Symp. Ser. 41:95-98.

Hantsis-Zacharov, E., and M. Halpern. 2007. Culturable psychrotrophic bacterial communities in raw milk and their proteolytic and lipolytic traits. Appl. Environ. Microbiol. 73:7162-7168. https:// doi.org/10.1128/AEM.00866-07.

Huang, X., and A. Madan. 1999. CAP3: A DNA sequence assembly program. Genome Res. 9:868-877. https://doi.org/10.1101/gr.9.9 .868 .

Huck, J. R., B. H. Hammond, S. C. Murphy, N. H. Woodcock, and K. J. Boor. 2007. Tracking spore-forming bacterial contaminants in milk fluid milk-processing systems. J. Dairy Sci. 90:4872-4883. https://doi.org/10.3168/jds.2007-0196. 
Hull, R. R., S. Toyne, I. N. Haynes, and F. L. Lehmann. 1992. Thermoduric bacteria: A re-emerging problem in cheesemaking. Aust. J. Dairy Technol. 47:91-94.

Khanal, S. N., S. Anand, K. Muthukumarappan, and M. Huegli. 2014 Inactivation of thermoduric aerobic sporeformers in milk by ultrasonication. Food Control 37:232-239. https://doi.org/10.1016/ j.foodcont.2013.09.022.

Knight, G. C., R. S. Nicol, and T. A. McMeekin. 2004. Temperature step changes: A novel approach to control biofilms of Streptococcus thermophilus in a pilot plant-scale cheese-milk pasteurisation plant. Int. J. Food Microbiol. 93:305-318. https://doi.org/10 .1016/j.ijfoodmicro.2003.11.013.

Kumar, S., G. Stecher, and K. Tamura. 2016. MEGA7: Molecular Evolutionary Genetics Analysis version 7.0 for bigger datasets. Mol. Biol. Evol. 33:1870-1874. https://doi.org/10.1093/molbev/ msw054.

Lewis, M. J. 2003. Improvements in the pasteurisation and sterilisation of milk. Pages 81-103 in Dairy Processing: Improving Quality. G. Smit, ed. Woodhead, Cambridge, UK.

Marchand, S., K. Coudijzer, M. Heyndrickx, K. Dewettinck, and J. De Block. 2008. Selective determination of the heat-resistant proteolytic activity of bacterial origin in raw milk. Int. Dairy J. 18:514519. https://doi.org/10.1016/j.idairyj.2007.10.007.

McAuley, C. M., M. L. Britz, K. S. Gobius, and H. M. Craven. 2015. Prevalence, seasonality, and growth of enterococci in raw and pasteurized milk in Victoria, Australia. J. Dairy Sci. 98:8348-8358. https://doi.org/10.3168/jds.2015-9335.

McAuley, C. M., K. S. Gobius, M. L. Britz, and H. M. Craven. 2012. Heat resistance of thermoduric enterococci isolated from milk. Int. J. Food Microbiol. 154:162-168. https://doi.org/10.1016/j .ijfoodmicro.2011.12.033.

Murphy, S. C., N. H. Martin, D. M. Barbano, and M. Wiedmann. 2016. Influence of raw milk quality on processed dairy products: How do raw milk quality test results relate to product quality and yield? J. Dairy Sci. 99:10128-10149. https://doi.org/10.3168/jds 2016-11172.

Ortolani, M. B. T., A. K. Yamazi, P. M. Moraes, G. N. Viçosa, and L. A. Nero. 2010. Microbiological quality and safety of raw milk and soft cheese and detection of autochthonous lactic acid bacteria with antagonistic activity against Listeria monocytogenes, Salmonella spp., and Staphylococcus aureus. Foodborne Pathog. Dis. 7:175-180. https://doi.org/10.1089/fpd.2009.0390.

Osborne, C. A., M. Galic, P. Sangwan, and P. H. Janssen. 2005. PCRgenerated artefact from $16 \mathrm{~S}$ rRNA gene-specific primers. FEMS Microbiol. Lett. 248:183-187. https://doi.org/10.1016/j.femsle .2005 .05 .043

Petrus, R. R., C. G. Loiola, and C. A. F. Oliveira. 2010. Microbiological shelf life of pasteurized milk in bottle and pouch. J. Food Sci. 75:M36-M40. https://doi.org/10.1111/j.1750-3841.2009.01443.x.

Ranieri, M. L., J. R. Huck, M. Sonnen, D. M. Barbano, and K. J. Boor. 2009. High temperature, short time pasteurization temperatures inversely affect bacterial numbers during refrigerated storage of pasteurized fluid milk. J. Dairy Sci. 92:4823-4832. https://doi .org/10.3168/jds.2009-2144.

Ranieri, M. L., R. A. Ivy, W. R. Mitchell, E. Call, S. N. Masiello, M. Wiedmann, and K. J. Boor. 2012. Real-time PCR detection of Paenibacillus spp. in raw milk to predict shelf life performance of pasteurized fluid milk products. Appl. Environ. Microbiol. 78:5855-5863. https://doi.org/10.1128/AEM.01361-12.

Reginensi, S. M., M. J. González, J. A. Olivera, M. Sosa, P. Juliano, and J. Bermúdez. 2011. RAPD-based screening for spore-forming bacterial populations in Uruguayan commercial powdered milk. Int. J. Food Microbiol. 148:36-41. https://doi.org/10.1016/j .ijfoodmicro.2011.04.020.

Ribeiro Júnior, J. C., V. Beloti, F. P. Massi, and M. H. P. Fungaro. 2017. Thermoduric psychrotrophic proteolytic microbiota from refrigerated raw milk. Semin. Cienc. Agrar. 38:267-272. https://doi .org/10.5433/1679-0359.2017v38n1p267.

Ribeiro Júnior, J. C., B. K. de Alcântara, and V. Beloti. 2016a. Spoilage potential of Paenibacillus spp. in Brazilian raw milk. Cienc. Rural 46:637-640. https://doi.org/10.1590/0103-8478cr20150810.

Ribeiro Júnior, J. C., A. M. de Oliveira, F. G. Silva, R. Tamanini, A. L. M. de Oliveira, and V. Beloti. 2018. The main spoilagerelated psychrotrophic bacteria in refrigerated raw milk. J. Dairy Sci. 101:75-83. https://doi.org/10.3168/jds.2017-13069.

Ribeiro Júnior, J. C., R. Tamanini, L. C. C. da Silva, and V. Beloti. 2015. Quality of milk produced by small and large dairy producers. Semin. Cienc. Agrar. 36:883-888. https://doi.org/10.5433/ 1679-0359.2015v36n2p883.

Ribeiro Júnior, J. C., R. Tamanini, B. F. Soares, A. M. de Oliveira F. G. Silva, F. F. da Silva, N. A. Augusto, and V. Beloti. 2016b. Efficiency of boiling and four other methods for genomic DNA extraction of deteriorating spore-forming bacteria from milk. Semin. Cienc. Agrar. 37:3069-3078. https://doi.org/10.5433/1679-0359 .2016v37n5p3069

Sneath, P. H., and R. R. Sokal. 1973. Numerical Taxonomy: The Principles and Practice of Numerical Classification. Freeman, San Francisco, CA.

Sørhaug, T., and L. Stepaniak. 1997. Psychrotrophs and their enzymes in milk and dairy products: Quality aspects. Trends Food Sci. Technol. 8:35-41. https://doi.org/10.1016/S0924-2244(97)01006-6.

Taponen, S., E. Liski, A. M. Heikkilä, and S. Pyörälä. 2017. Factors associated with intramammary infection in dairy cows caused by coagulase-negative staphylococci, Staphylococcus aureus, Streptococcus uberis, Streptococcus dysgalactiae, Corynebacterium bovis, or Escherichia coli. J. Dairy Sci. 100:493-503. https://doi.org/10 .3168/jds.2016-11465.

te Giffel, M. C., A. Wagendorp, A. Herrewegh, and F. Driehuis. 2002. Bacterial spores in silage and raw milk. Antonie van Leeuwenhoek 81:625-630. https://doi.org/10.1023/A:1020578110353.

Torp, M., G. Holstad, and P. E. Granum. 2001. Bacillus cereus-Feeds and feces as major contamination sources in milk on a dairy farm. Nor. Vet.-Tidsskr. 113:462-466. https://doi.org/10.3168/jds.S0022 -0302(99)75237-9.

Vissers, M. M. M., F. Driehuis, M. C. te Giffel, P. De Jong, and J. M. G. Lankveld. 2007. Concentrations of butyric acid bacteria spores in silage and relationships with aerobic deterioration. J. Dairy Sci. 90:928-936. https://doi.org/10.3168/jds.S0022-0302(07)71576-X.

Yuan, D. D., G. C. Liu, D. Y. Ren, D. Zhang, L. Zhao, C. P. Kan, Z. Y. Yang, W. Maa, Y. Li, and L. B. Zhang. 2012. A survey on occurrence of thermophilic bacilli in commercial milk powders in China. Food Control 25:752-757. https://doi.org/10.1016/j foodcont.2011.12.020. 